\title{
FABRICATION OF DYE SENSITIZED SOLAR CELL USING SPINACH VEGETABLE EXTRACT AS SENSITIZING DYE
}

\author{
AWOBOKUN, David Imoleayo ${ }^{1}$ and Dr. Mohammed Umar Garba ${ }^{1}$ \\ ${ }^{1}$ Post Graduate Scholar and ${ }^{2}$ Associate professor \\ Department of Chemical Engineering \\ Federal University of Technology \\ Minna, Nigeria
}

\begin{abstract}
Dye-sensitized solar cell using spinach vegetable extract as sensitizing dye was fabricated in this study as an alternative source of renewable energy generation (electricity). Soxhlet apparatus was used for the extraction of the dye pigments from the spinach vegetable with ethanol as the extracting agent. The result from the Fourier Transform Infrared spectra indicates the presence of chlorophyll in the spinach vegetable dye pigments and the result from the UV-Visible absorption spectra with seven peaks between 400nm and 700nm wavelengths also indicates that the spinach vegetable dye pigments is capable of absorbing light. Titanium dioxide was used as the wide band gap semiconducting layer and was deposited on the surface of transparent conducting oxide (Fluorine-doped Tin Oxide substrate) using doctor blade method and then sintered with a hotplate at 4500C for 30 minutes The carbon electrode was obtained by depositing the carbon soot from candle flame on the conductive side of the second Fluorine-doped Tin Oxide glass, the Dye-sensitized solar cell was assembled by clamping the two electrodes together using two binder clips and iodine redox electrolyte solution was added drops on one edge of the electrode sandwich. The fabricated Dye-sensitized solar cell was tested for its photovoltaic characteristics at intervals of one hour from 11 am immediately after fabrication to $4 \mathrm{pm}$ on the same day with illumination from sunlight. The results show that the fabricated dye-sensitized solar cell is a good renewable source of generating energy (electricity) with the highest power conversion efficiency of $4 \%$ at 11 am and lowest power conversion efficiency of $1.74 \%$ at 3 pm, the highest fill factor of 0.68 was obtained at 3 pm, also the highest short circuit current density of 2.19( $\mathrm{mA}$ ) was obtained at 11 am immediately after fabrication and highest open circuit voltage of $4.15(\mathrm{mV})$ at $4 \mathrm{pm}$ when the short circuit current density was $O(\mathrm{~mA})$ due to the leakage of redox species in the electrolyte as a result of the drying effects from sunlight.
\end{abstract}

Keywords: Dye Sensitized Solar Cell, Natural Dyes, Spinach Vegetable, Low Cost Solar Cell, Titanium Dioxide Nanoparticles.

\section{INTRODUCTION}

Dye Sensitized solar cells also usually referred to as dye sensitized cell, belongs to the third generation of photovoltaic (solar) cell which transforms any visible light into electrical energy (Monzir et al., 2015). This recent class of advanced solar cell can be similarly linked to engineered photosynthesis due to the manner in which it tries duplicating nature's absorption of light energy. Dye Sensitized solar cells were proposed in the year 1991 by Professor Michael Graetzel and Dr Brian O’Regan at École Poly technique Fédérale de Lausanne (EPFL), Switzerland and is often known as the Gräetzel cell (Wikipedia). Dye-Sensitized Solar Cells is an innovative technology that can be used to produce electricity in a vast range of light experience, indoors and outdoors, allowing the applicant to transform both artificial and natural light into energy to provide sufficient amount of power for a wide range of electronic devices (Wikipedia). Its basis is laid on a semiconductor formed between a photo-sensitized anode and a counter electrode along with an electrolyte in the photo-electrochemical system (Giuseppe et al., 2014). The Dye-Sensitized Solar Cells has a number of desired and quite compelling features; it is simple to make, its semi-flexible, mobile and most of the materials used are cost and user friendly (Sofyan et al., 2013).

The Structure of Dye-sensitized solar cell is generally composed of a photoactive working electrode of titanium dioxide, and a counter electrode coated with Carbon Soot and the electrolyte (Mary et al., 2014). The dye used in Dye-sensitized solar cell acts 
as a photosensitizer allowing solar energy to be converted to electrical energy. The type of dye used in a Dye-sensitized solar cell is one of the most crucial components that influences the efficiency of DSSC (Sofyan et al., 2013). The dye is contained in the photo-anodes that are responsible for better absorbance and stronger electron excitation properties, conclusively granting more efficient solar cell (Lawrence et al., 2015).

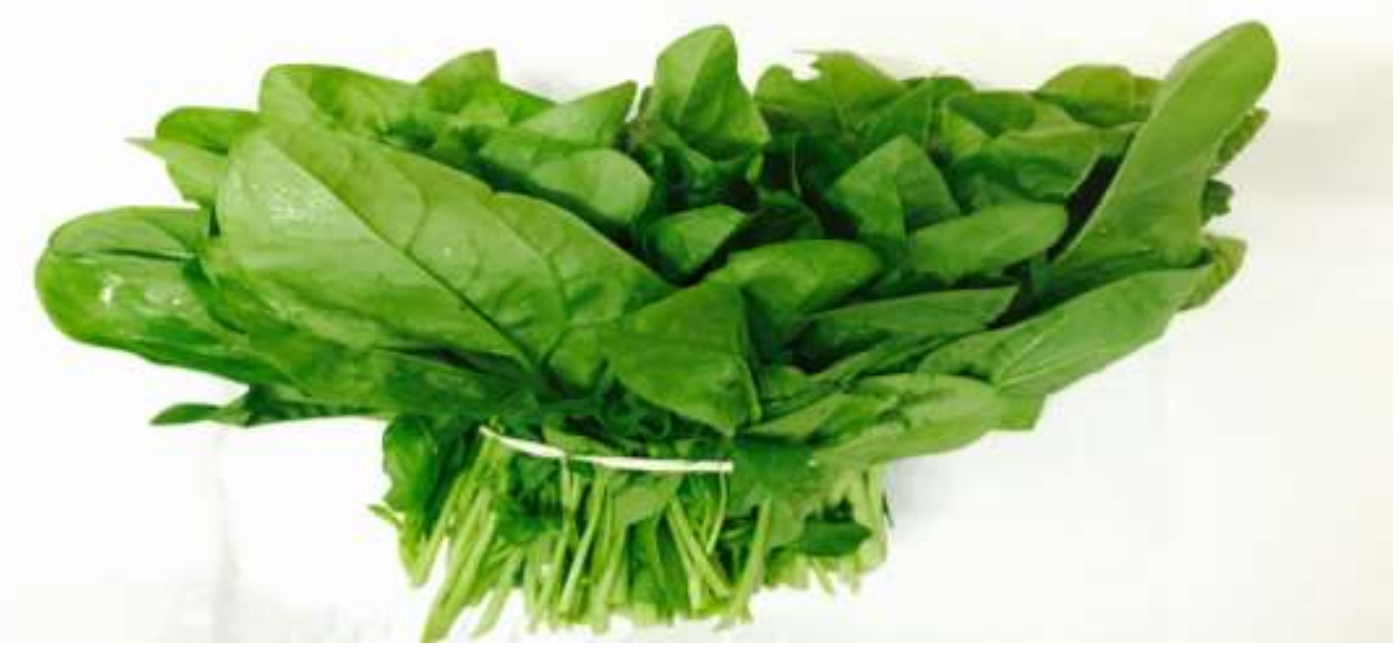

Figure 1.1: Spinach vegetable

When a Dye-sensitized solar cell is illuminated with a light source, the dye molecules that is adsorbed on a layer of wide bandgap semiconducting layer on the transparent conducting oxide becomes excited, then the excited dye molecule injects an electron into the wide bandgap semiconducting layer. The electron is then transported to the transparent conducting oxide, where it is gathered and moved through a load and converted into electricity (Syafinar et al., 2015; Khan, 2013).

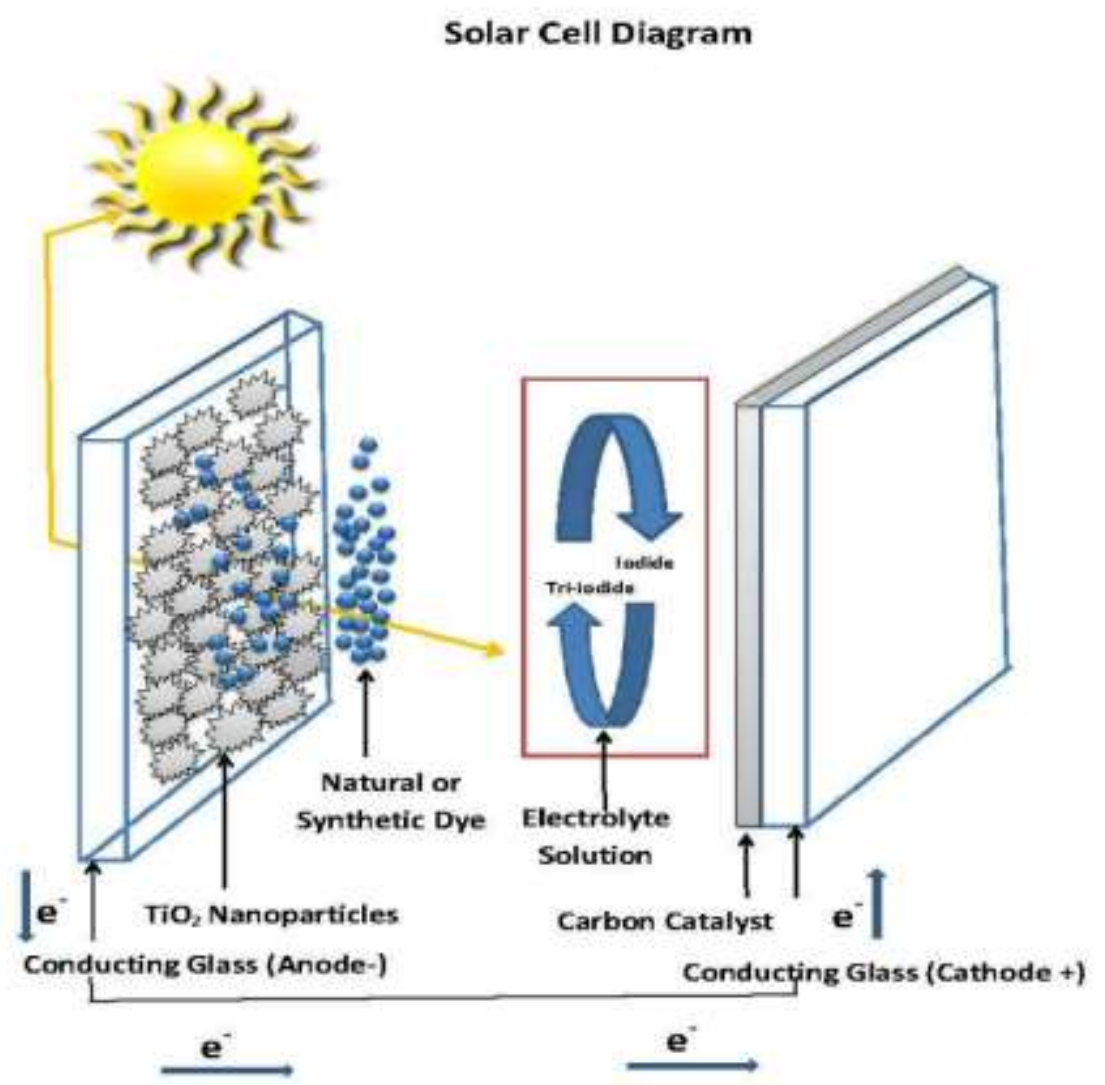

Figure 1.2: Working principle of a Dye-sensitized solar cell 
Nigeria is tagged incompetent when matters pertaining to electricity generation is analyzed, in Nigeria, fossil fuels has been concluded to be the most dependent source of energy generation (electricity), apart from the hydropower electricity generation. Excessive exploitation of fossil fuels, cost of fossil fuels (such as gasoline and diesel) and by-products from fossil fuels application, has led to problems such as; the degradation of the environment, exposure to global warming, deteriorating health conditions and scarcity. These problems have prompted researchers to find solutions by creating an alternative means of energy generation that is efficient, environmental friendly and cost effective. This alternate means of energy generation can also help in Combating unemployment and finding means by which jobs can be created, Safeguard lives and the state of the global environment in general, encourage privatization and promoting entrepreneurial ambitions, reduction and in turn the extinction of only one dependable means of generating electricity, increase foreign revenue and stability of electricity.

The problem, however is, crystalline silicon-based solar cells have been known to have the highest power conversion efficiency also have been the most popularly used mode of solar energy generation, but its production procedures during the processing of silicon and its installation are high in cost and not everyone, particularly in Nigeria can afford the use of the silicon-based solar cells for the generation of solar energy as an alternative means of generating electricity thus, leading to the introduction of dye sensitized solar cell which is a low cost solar cell. (Katja, 2011).

In the fabrication of Dye sensitized solar cells, the most widely used dyes with the highest power conversion efficiency of over $10 \%$ that have been reported have been Ruthenium (II) based dyes, they have good light absorption properties and long excited lifetime (Hassan et al., 2017; Grätzel, 2003), but the disadvantages of this ruthenium (II) based dyes is that they are expensive rare metals and require complex multi-step synthesis that involves toxic and environmental harmful chemicals which are not sustainable for mass-scale application (Hemmatzadeh and Mohammadi, 2013). In the last couple of years, a novel approach has been studied where a perovskite based dye (however, still a toxic element) has been studied and high efficiencies have been reported. Besides these dyes, natural dyes have shown promising properties as efficient photo-sensitizing agent for the production of dye sensitized solar cells. Natural dyes, especially dye extract from spinach vegetable are an attractive option since they are easily available, nontoxic, low-cost, environmental friendly (Ana, 2015).

\subsection{EXPERIMENTAL/RESEARCH WORK}

\subsection{Extraction of Dye Pigments From Spinach Vegetable}

The extraction of the dye(sensitizer) from the spinach vegetable was carried out using Soxhlet apparatus after the spinach vegetable obtained was washed with plenty amount of running water to remove surface impurities, dried in an oven for four hours at $30^{\circ} \mathrm{C}$ to remove the water content and grinded with a blender into powdered form (Mary et al, 2014).

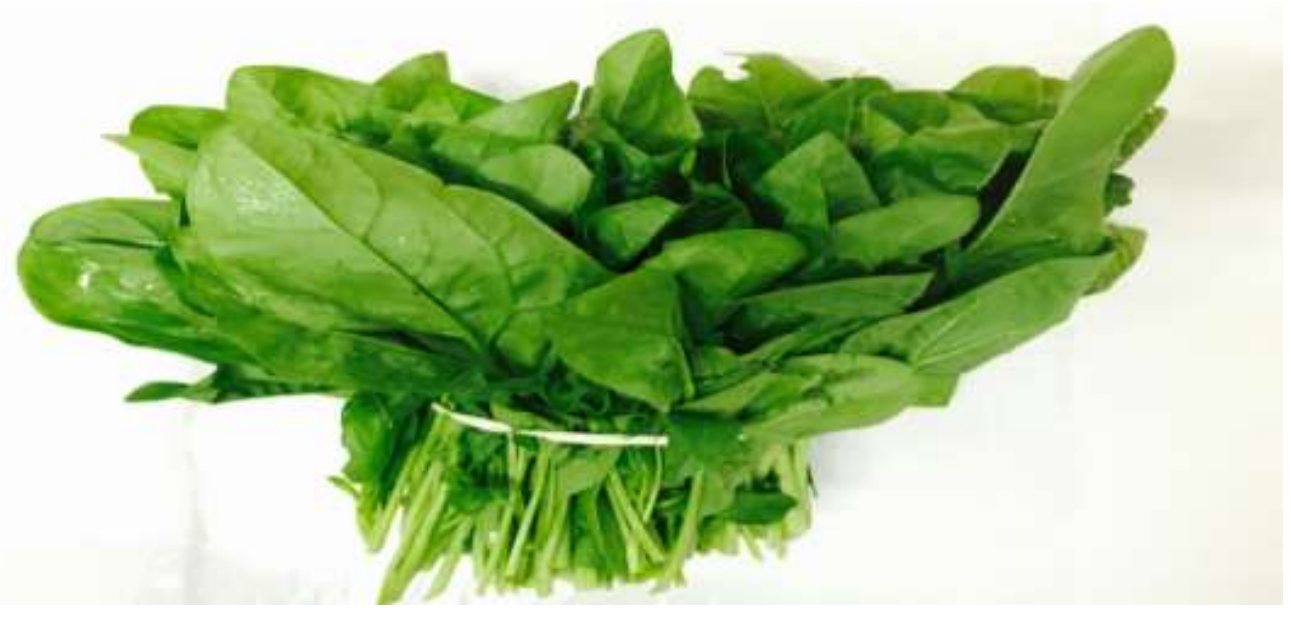

Figure 2.1: Spinach vegetable 


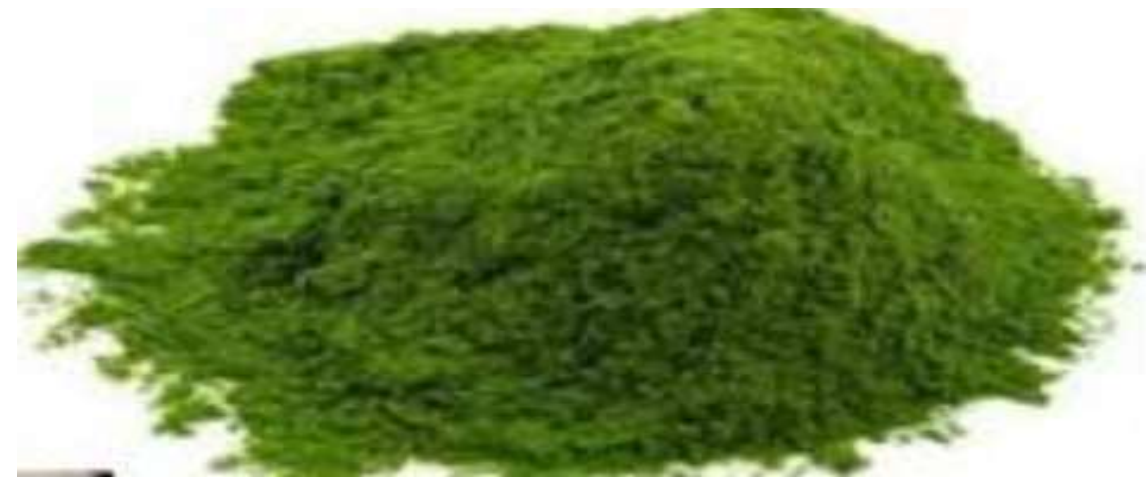

Figure 2.2: Spinach vegetable powder

\subsection{Fabrication Of The Dye Sensitized Solar Cell}

Fabrication of the Dye Sensitized solar cell involves the preparation of the photo-anode, the preparation of the counter electrode and the application of the iodine electrolyte (Mohamed et al., 2016).

\subsubsection{Preparation Of The Photo-anode}

The photo-anode consists of one Fluorine-doped Tin Oxide glass, titanium dioxide semiconductor and the spinach vegetable dye. The preparation of the photo-anode is as follows; First, the multi-meter was used to determine the Conductive side of the Fluorine-doped Tin Oxide glass, then after, Scotch tape was used to make a 3-sided border on the surface of the conductive surface of the Fluorine-doped Tin Oxide glass to ensure a $1 \mathrm{~cm}^{2}$ working electrode (Mary et al., 2014; Smestad et al., 1998). Afterwards, the preparation of titanium dioxide paste was carried out by adding 18grams of titanium dioxide powder (anatase) into the mortar and pestle and dilute acetic acid (vinegar), which has been previously prepared by diluting $8 \mathrm{ml}$ of concentrated acetic acid ( $\mathrm{pH} \mathrm{3-4)} \mathrm{with} \mathrm{50ml} \mathrm{of} \mathrm{distilled} \mathrm{water} \mathrm{was} \mathrm{added} \mathrm{in} \mathrm{drops} \mathrm{into} \mathrm{the} \mathrm{anatase} \mathrm{powder} \mathrm{in} \mathrm{the} \mathrm{mortar} \mathrm{and} \mathrm{pestle} \mathrm{and} \mathrm{then} \mathrm{the}$ mixture was grinded continuously to make a paste. 4grams of powdered surfactant was added to the mixture and was lightly stirred to improve the adhesion of the titanium dioxide Nano-crystalline mixture when deposited on the Fluorine-doped Tin Oxide glass (Ridwan et al., 2018). The paste was allowed to dry at room temperature for about 30 minutes (Muhamad et al., 2015; Mary et al., 2014).

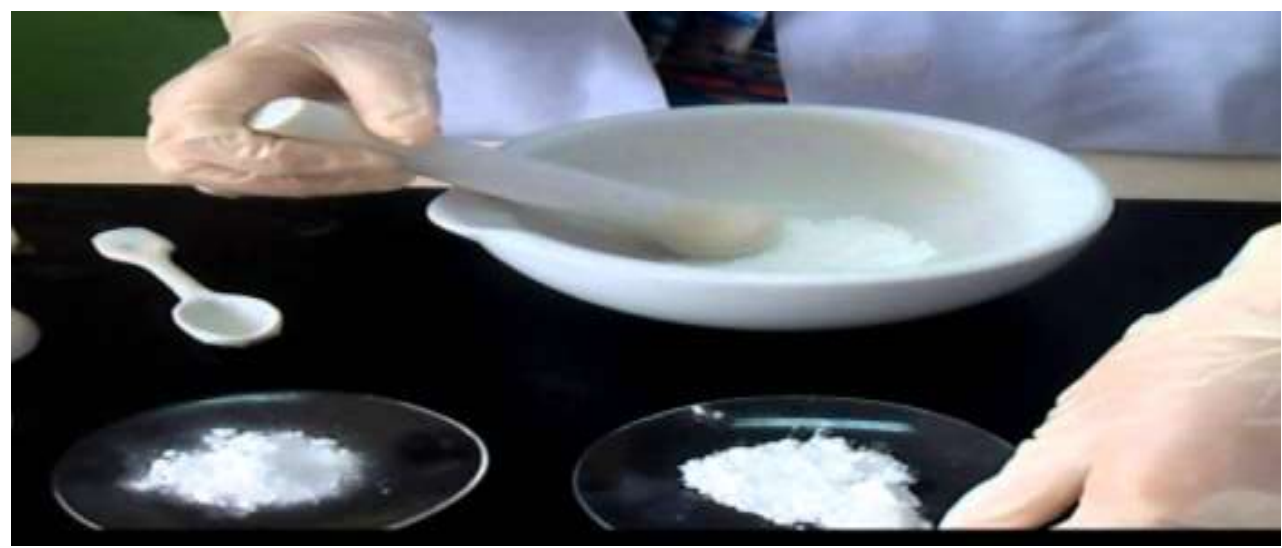

Figure 2.3: Preparation of the Titanium dioxide $\left(\mathrm{TiO}_{2}\right)$ paste

The titanium dioxide mixture was applied on the conductive side of the Fluorine-doped Tin Oxide glass using the doctor blade method. Then after, the Fluorine-doped Tin Oxide glass with the titanium dioxide film was placed on a hot plate and sintered at $450^{\circ}$ for about 30 minutes, after that, it was allowed to sit and cool for about 1 hour at room temperature. (Mary et al., 2014; Monzir et al., 2016; Smestad, et al., 1998). 

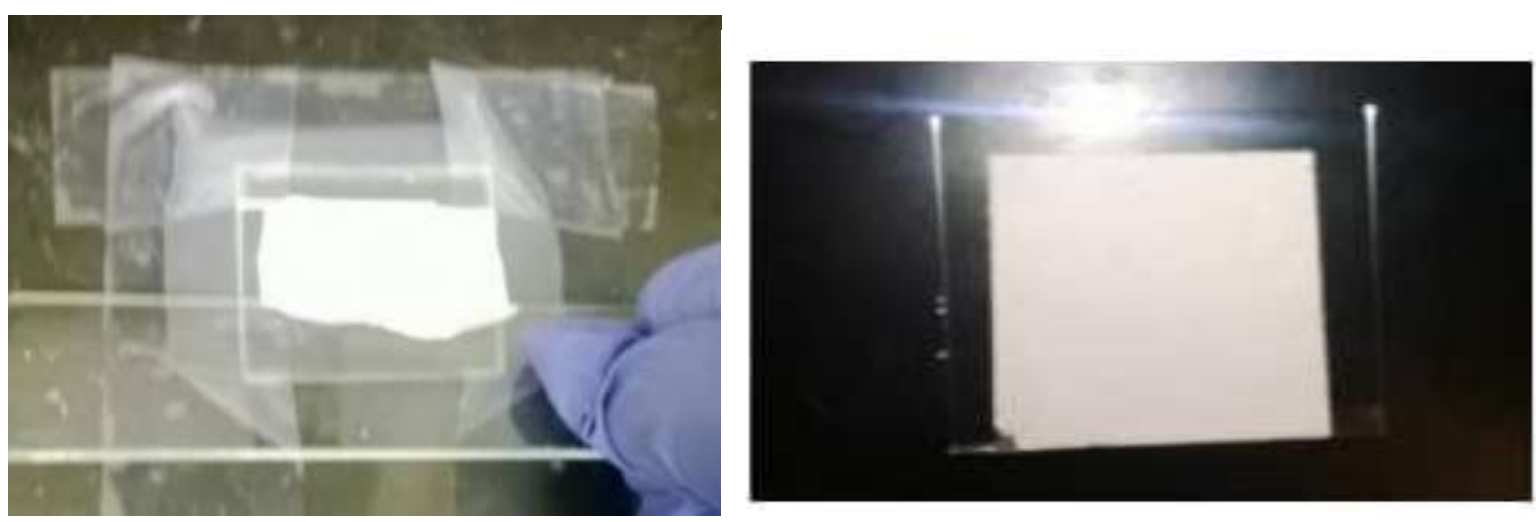

Figure 2.4: Deposition of the $\left(\mathrm{TiO}_{2}\right)$ paste on the Fluorine-doped Tin Oxide glass using doctor blade method

The titanium dioxide coated side of the Fluorine-doped Tin Oxide glass was soaked in the prepared spinach dye extract in a Petri dish overnight for about 16 hours, it was covered and kept out of light. After that, it was dried in another petri dish and kept out of light before proceeding with the assembling of the dye sensitized solar cell (Mary et al., 2014).

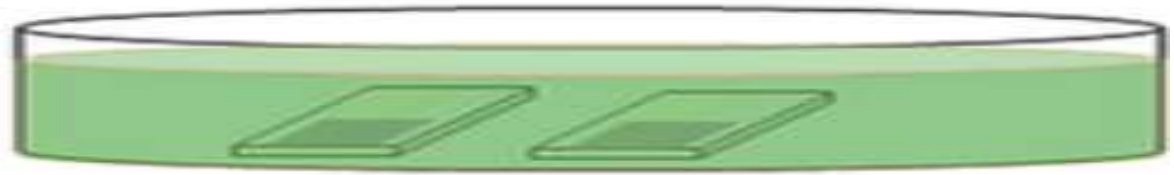

Figure 2.5: Sensitization of the titanium dioxide film on the Fluorine-doped Tin Oxide glass with dye extract

\subsubsection{Preparation Of The Counter Electrode}

The carbon electrode was obtained by holding the conductive side of the second Fluorine-doped Tin Oxide glass over a candle flame for about one hour, thereby depositing the soot (carbon) from the burning candle on the surface of the conductive side of the Fluorine-doped Tin Oxide glass, and was allowed to cool at room temperature and the scotch tape used to make the 3 sided boarder was removed (Smestad, et al., 1998; Pratiwi et al., 2016).

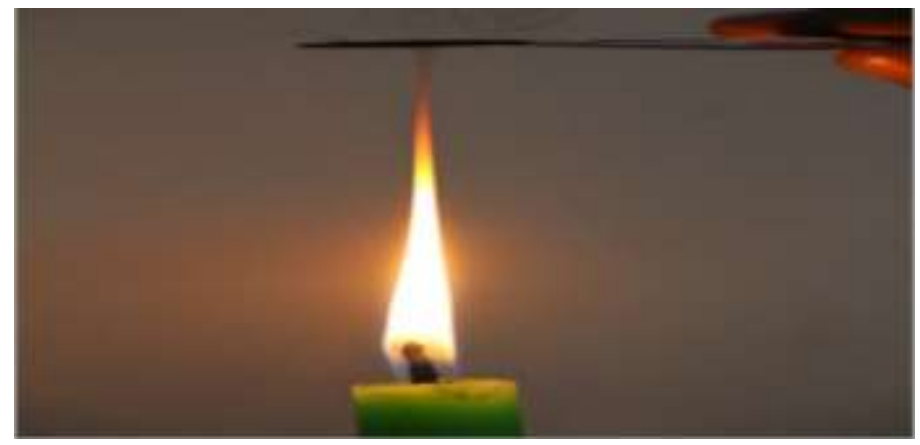

Figure 2.6: Preparation of the counter electrode

\subsubsection{Assembling The Dye Sensitized Solar Cell}

After the dye sensitized titanium dioxide electrode is dry and the carbon electrode is cool. The dye sensitized titanium dioxide electrode was placed face up on the lab bench and the counter electrode was placed on top of it, offsetting it so that the film is covered by the counter electrode, but there is about $1 / 8$ of the dye sensitized titanium electrode and the counter electrode glasses exposed for connections with the alligator clips. The two electrodes were clamped together using two binder clips. After which the $\mathrm{I} / \mathrm{I}^{3-}$ redox electrolyte solution was added in drops on one edge of the electrode sandwich (Smestad, et al., 1998; Lawrence et al., 2015; Monzir et al., 2016). 


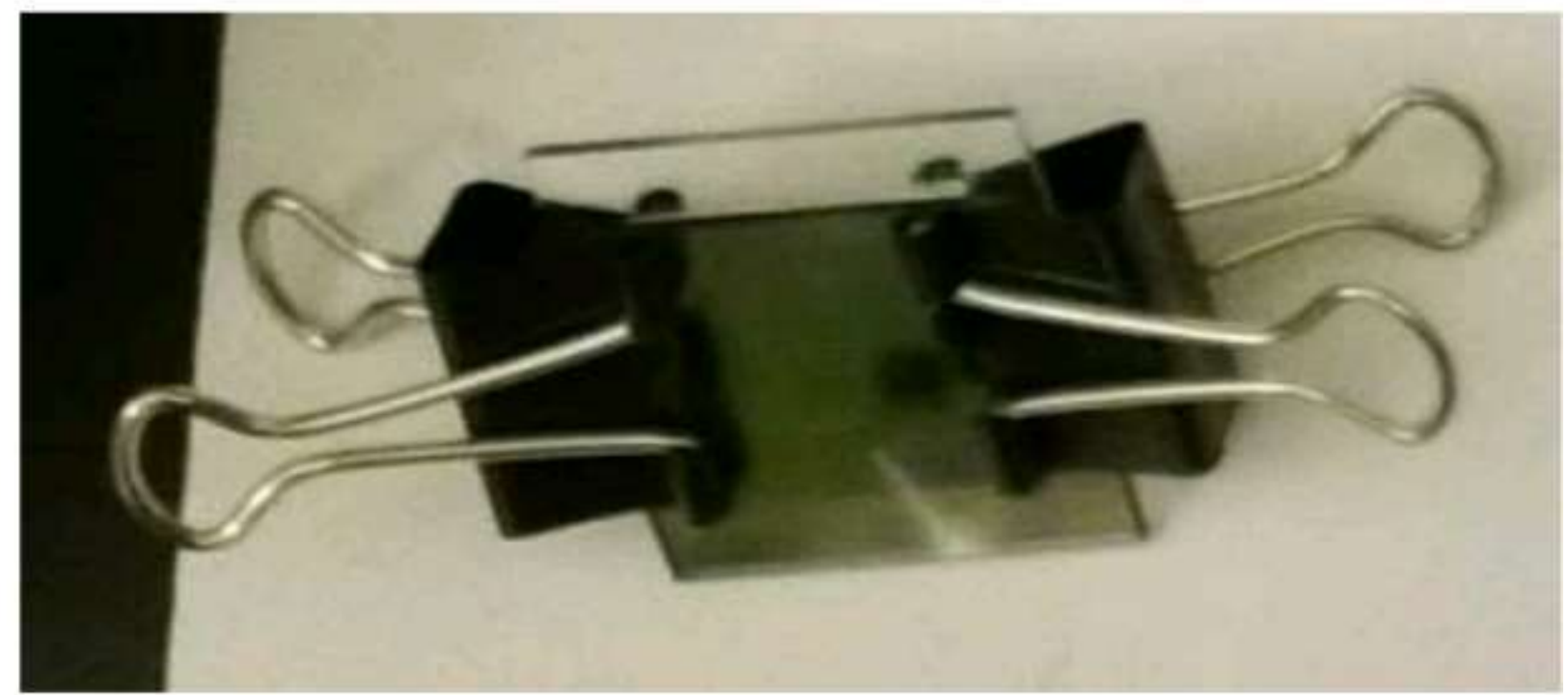

Figure 2.7: Picture of an assembled Dye-sensitized solar cell

\subsection{RESULTS AND DISCUSSION}

\subsection{Fourier Transform Infrared Spectra (FTIR)}

Figure 3.1 below shows the FTIR spectra of the spinach vegetable dye, the peaks at $3749.74\left(\mathrm{~cm}^{-1}\right)$ and $3678.37\left(\mathrm{~cm}^{-1}\right)$ represents the $\mathrm{C}-\mathrm{H}$ stretches which is attributed to the $\mathrm{CH}_{3}$ group, the peak at $1791.93\left(\mathrm{~cm}^{-1}\right)$ represents the $\mathrm{C}=\mathrm{O}$ stretches and the peak at $1026.16 \mathrm{~cm}^{-1}$ represents the $\mathrm{C}-\mathrm{O}$ stretches, the peak at $920\left(\mathrm{~cm}^{-1}\right)$ represents the $\mathrm{C}-\mathrm{N}$ stretches which are inorganic elements. The broad peaks at $2557.69\left(\mathrm{~cm}^{-1}\right), 3446.91\left(\mathrm{~cm}^{-1}\right), 3578.07\left(\mathrm{~cm}^{-1}\right)$ represents the N-H stretches and O-H stretches that mainly occur from chlorophyll and carbohydrate, the peaks at $1699.34\left(\mathrm{~cm}^{-1}\right)$ and $1523.82\left(\mathrm{~cm}^{-1}\right)$ represents the attachment of Mg metal complex. The presence of these various peaks in the infrared region supports the complex structure of chlorophyll pigments (Suryawanshi et al., 2015).

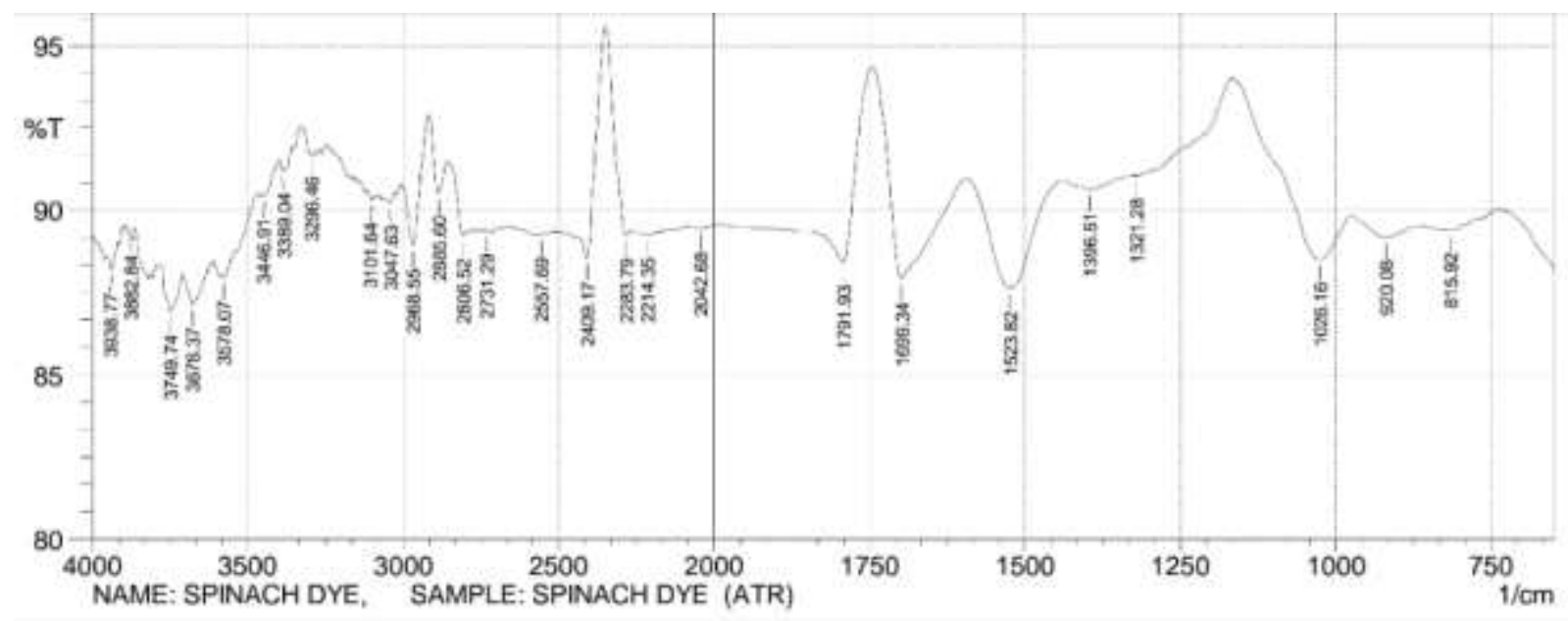

Figure 3.1: FTIR spectra of spinach vegetable dye (Use high resolution figure)

\subsection{UV-Visible Absorption spectra}

Figure 3.2 below represents the UV-Visible absorption spectra of spinach vegetable dye. The absorbance spectra of the dye were measured in visible light region between 400(nm) - 700(nm) and shows seven (7) absorption peaks at 413.30(nm), 446.50(nm), 473.50(nm), 533.50(nm), 555.00(nm), 609.50(nm), 668.00(nm). These peaks correspond to chlorophyll peaks present in the spinach vegetable dye which are advantageous to the absorption of dyes from light. Hence light absorbance was not a problem with the spinach vegetable dye as sensitizer for the Fabrication of Dye-sensitized solar cell from the result. 


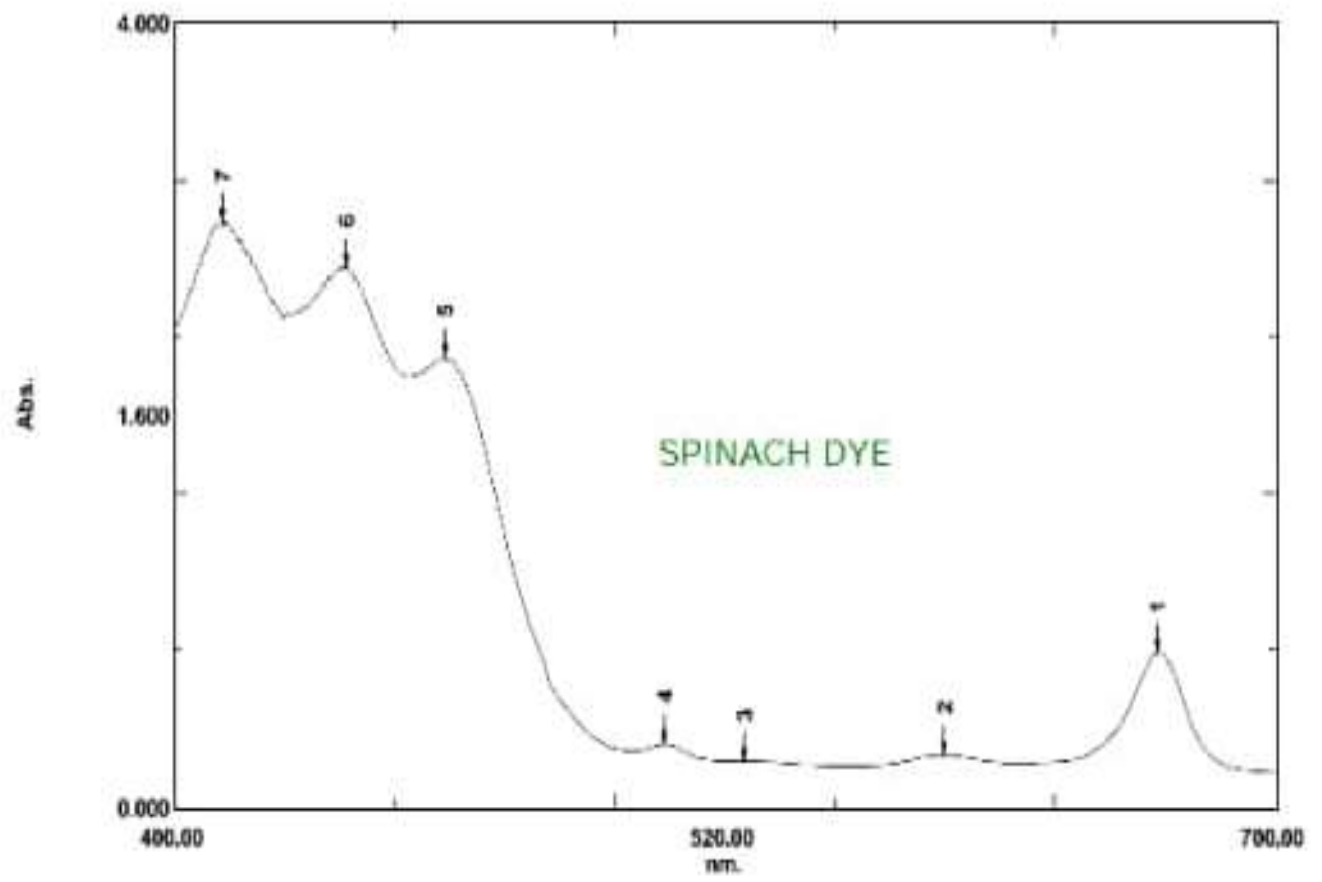

Figure 3.2: Absorption spectra of spinach vegetable dye (Use high resolution figure)

\subsection{Current-Voltage Characterization Of The Fabricated Dye Sensitized Solar Cell}

Current-Voltage characterization of the fabricated Dye-sensitized solar cell using spinach vegetable dye as sensitizer was performed by determining the Current-Voltage curve (I-V curve) of the Dye-sensitized solar cell under radiation with sunlight of $100\left(\mathrm{~mW} / \mathrm{cm}^{2}\right)$ intensity (Katja, 2011). The performance of spinach vegetable dye as sensitizer in Dye sensitized solar cell was evaluated by Short circuit current density (Jsc), Open circuit voltage (Voc), Fill factor (F.F), and power conversion efficiency ( $\eta$ ). Figure 3.3 below represents the Current-Voltage curves of the fabricated Dye-sensitized solar cell at $11 \mathrm{am}, 12 \mathrm{pm}, 1 \mathrm{pm}, 2 \mathrm{pm}$ and $3 \mathrm{pm}$.

A Current-Voltage curve was not obtained at $4 \mathrm{pm}$ because there was no current value obtained, that is, Isc $=0 \mathrm{~mA}$

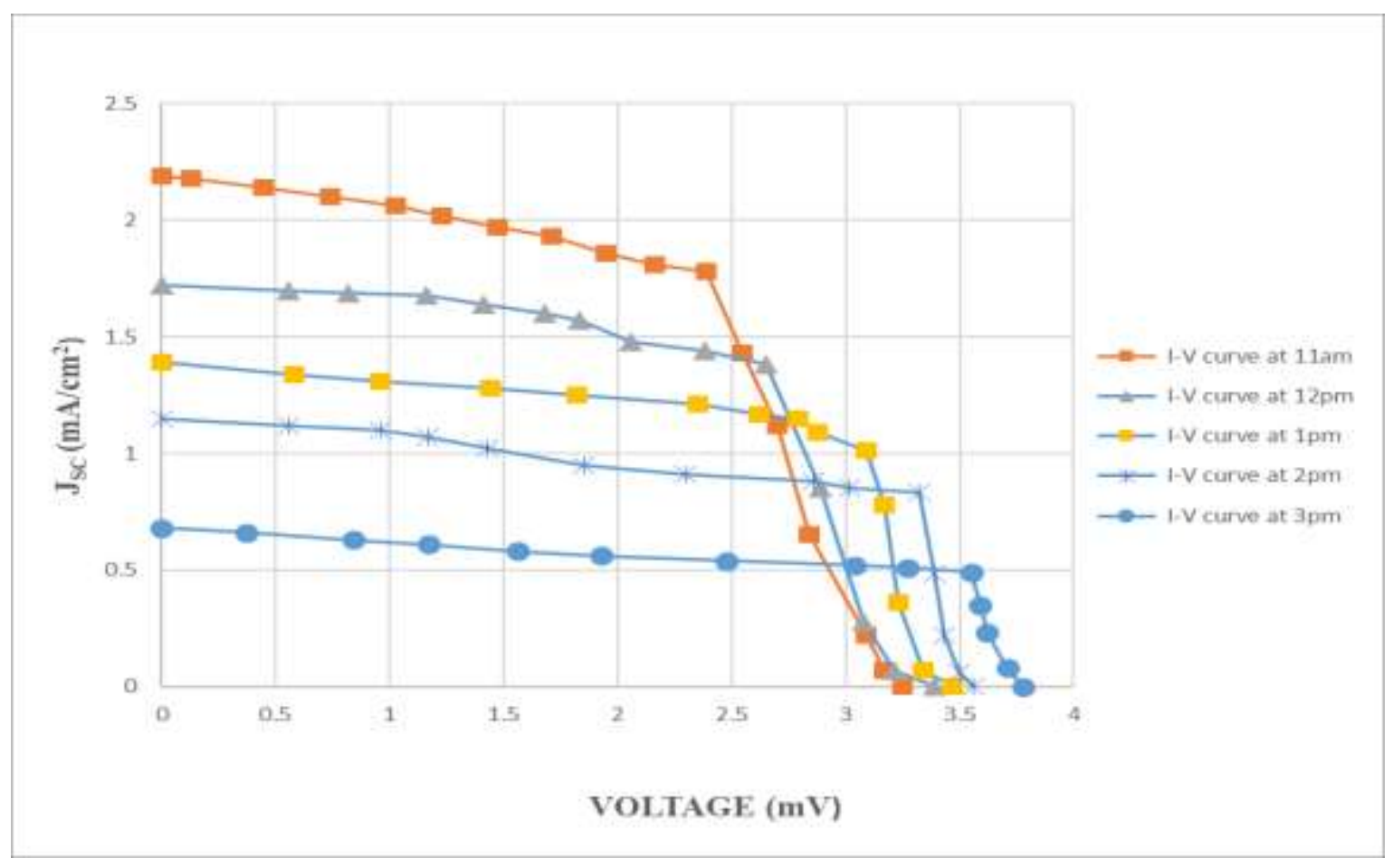

Figure 3.3: Current-Voltage Curves at 11am, 12pm, 1pm, 2pm and 3pm 
From the characteristic Current-Voltage curves in Figure 3.3, we can calculate several parameters such as the open circuit voltage (Voc), short circuit current density (Jsc), maximum voltage (Vmax), maximum current density (Imax), maximum power (Pmax), fill factor (FF) and efficiency $(\eta)$ that can be seen from Table 1 below;

Table 3: Summary of the photovoltaic characteristics of the Fabricated Dye Sensitized solar cells at 11am, 12pm, 1pm, 2pm, 3pm and 4pm on Wednesday, $26^{\text {th }}$ September, 2018

\begin{tabular}{|l|c|c|c|c|c|c|c|}
\hline \multicolumn{1}{|c|}{ Time } & $\mathbf{I}_{\mathbf{M A X}}(\mathbf{m A})$ & $\mathbf{V}_{\mathbf{M A X}}(\mathbf{m V})$ & Power(mW) & $\mathbf{J}_{\mathbf{S C}}\left(\mathbf{m A} / \mathbf{c m}^{2}\right)$ & $\mathbf{V}_{\mathbf{O C}}(\mathbf{m V})$ & $\mathbf{F F}$ & $\mathbf{y}(\mathbf{\%})$ \\
\hline $11 \mathrm{am}$ & 1.78 & 2.23 & 3.97 & 2.19 & 3.25 & 0.56 & 4.00 \\
\hline $12 \mathrm{pm}$ & 1.38 & 2.65 & 3.66 & 1.72 & 3.39 & 0.63 & 3.67 \\
\hline $1 \mathrm{pm}$ & 1.01 & 3.09 & 3.12 & 1.39 & 3.47 & 0.65 & 3.12 \\
\hline $2 \mathrm{pm}$ & 0.83 & 3.32 & 2.76 & 1.15 & 3.56 & 0.67 & 2.76 \\
\hline $3 \mathrm{pm}$ & 0.49 & 3.55 & 1.74 & 0.68 & 3.78 & 0.68 & 1.74 \\
\hline $4 \mathrm{pm}$ & & \multicolumn{7}{|l|}{} & 0.00 & 4.15 & & \\
\hline
\end{tabular}

\subsection{Effect of time on the Short Circuit Current density of the Dye Sensitized Solar Cell}

From Figure 3.4 below, the results show that, initially, there was a high value of short circuit current density (Jsc) of $2.19(\mathrm{~mA})$ at $11 \mathrm{am}$, but then there was decrease in the values of the short-circuit current density as time goes on to $1.72(\mathrm{~mA})$ at $12 \mathrm{pm}$ to $1.39(\mathrm{~mA})$ at $1 \mathrm{pm}$ to $1.15(\mathrm{~mA})$ at $2 \mathrm{pm}$ to $0.68(\mathrm{~mA})$ at $3 \mathrm{pm}$ and then to $0(\mathrm{~mA})$ at $4 \mathrm{pm}$. This gradual decrease in short circuit current density was as a result of dye desorption, resistive losses which are mainly linked to the electron transfer resistance at carbon counter electrode-electrolyte interface to reduce the oxidized electrolyte and resistance due to the diffusion of redox species in the electrolyte as a result of gradual electrolyte leakage from the drying effects of sunlight (Zhibin et al., 2012). Desorption of the dye was as a result of continuous oxidation of the dye after electron is being transferred into the wide bandgap semiconductor mesoporous titanium dioxide film. Continuous desorption occurs until the mesoporous titanium dioxide film is bare and without reduced dye to absorb light and to transfer electrons, at this stage, the short circuit current was 0 (mA), which shows that there was no photo-excited dye to transfer electrons into the conduction band of the titanium dioxide film. The decrease in short circuit current density was also as a result of electron recombination resistance at the carbon counter electrode/electrolyte interface to reduce the oxidized electrolyte that has been used for the regeneration of the dye during the operation of the Dye sensitized solar cell. The decrease in short circuit current density as time goes on was also due to the diffusion of redox species in the electrolyte as a result of gradual leakage from the drying effect from sunlight (Ru-YuanYang et al., 2012); Parth et al., 2016).

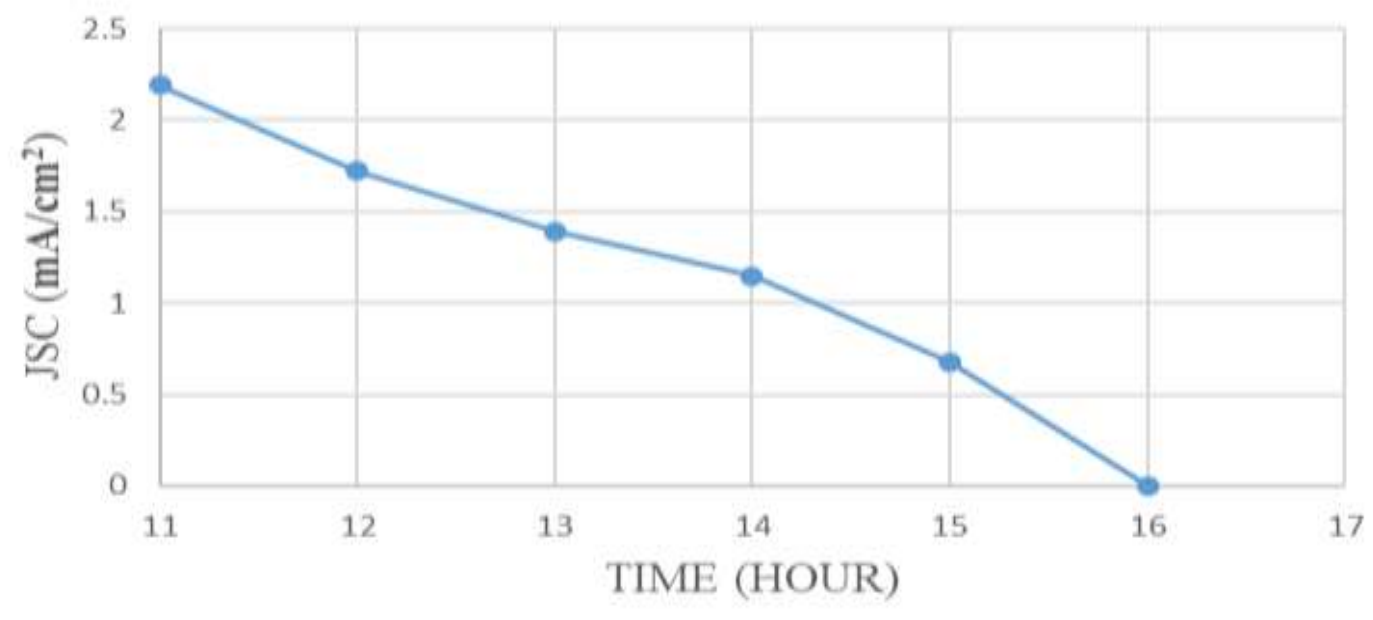

Figure 3.4: Effect of time on the Short Circuit Current density

\subsection{Effect Of Time On The Open Circuit Voltage}

There was increase in open circuit voltage from $3.25(\mathrm{mV})$ at $11 \mathrm{am}$ to $3.39(\mathrm{mV})$ at $12 \mathrm{pm}$ to $3.47(\mathrm{mV})$ at $1 \mathrm{pm}$ to $3.56(\mathrm{mV})$ at $2 \mathrm{pm}$ to $3.78(\mathrm{mV})$ at $3 \mathrm{pm}$ to $4.15(\mathrm{mV})$ at $4 \mathrm{pm}$, this increase in open circuit voltage was as a result of the presence of electron and the electron lifetime in the Dye sensitized solar cell (Zhibin et al., (2012). The close contact formation of the two Fluorine-doped Tin Oxide substrate also contributed to the increase in open circuit voltage as time goes on. The increase in open circuit voltage 
can also be attributed to greater photon flux received by the dye from sunlight, the continuous oxidation and reduction of $\mathrm{I}^{3-}$ concentration and continuous oxidation and reduction of sensitizing dye (Parth et al., 2016; Ru-YuanYang et al., 2012).

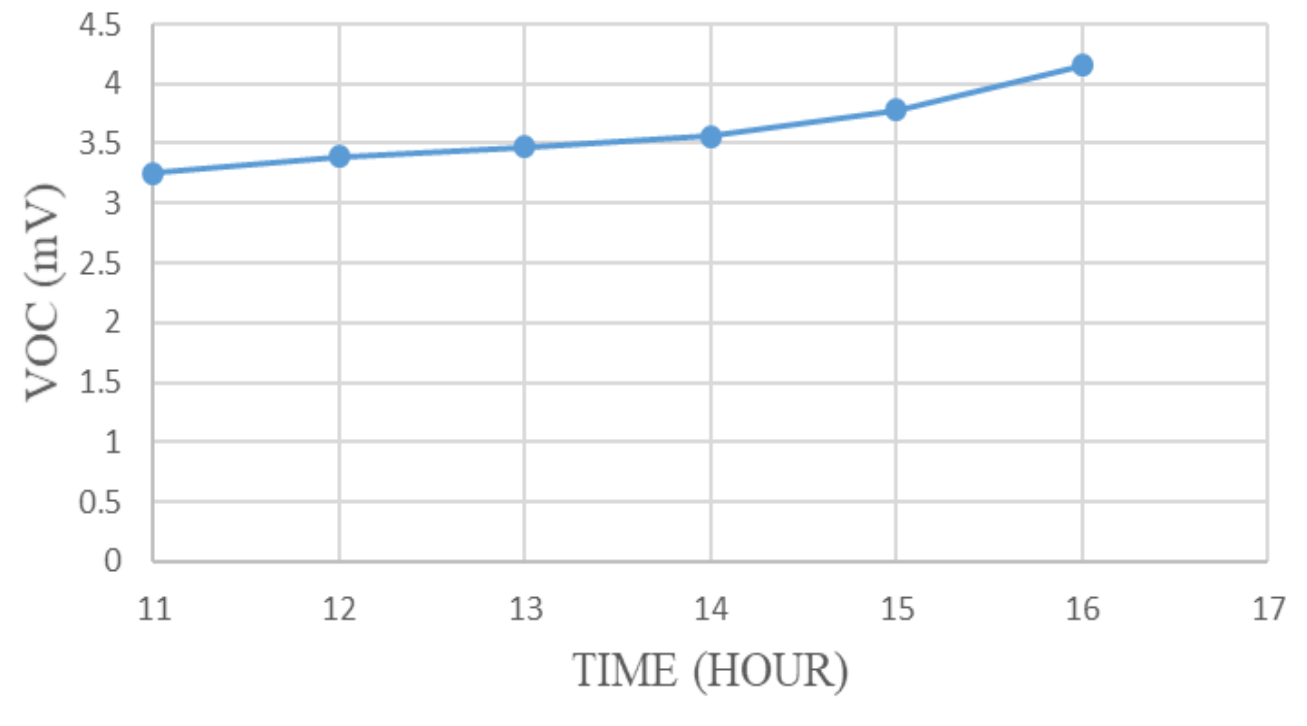

Figure 3.5: Effect of time on the Open circuit voltage

\subsection{Effect Of Time On The Maximum Power}

There was decrease in the maximum power from $3.97(\mathrm{~mW})$ at $11 \mathrm{am}$ to $3.66(\mathrm{~mW})$ at $12 \mathrm{pm}$ to $3.12(\mathrm{~mW})$ at $1 \mathrm{pm}$ to $2.76(\mathrm{~mW})$ at $2 \mathrm{pm}$ to $1.74(\mathrm{~mW})$ at $3 \mathrm{pm}$, this was as a result of the decrease in the short circuit current $\left(\mathrm{I}_{\mathrm{SC}}\right)$. From Ohm's law relationship, electrical Power is directly proportional to the current and voltage value obtained from an electrical device (Wikipaedia). Hence, the decrease in short circuit current density was the major cause for the decrease in maximum power of the Dye-sensitized solar cell as time goes on (Ru-YuanYang et al., 2012; Parth et al., 2016).

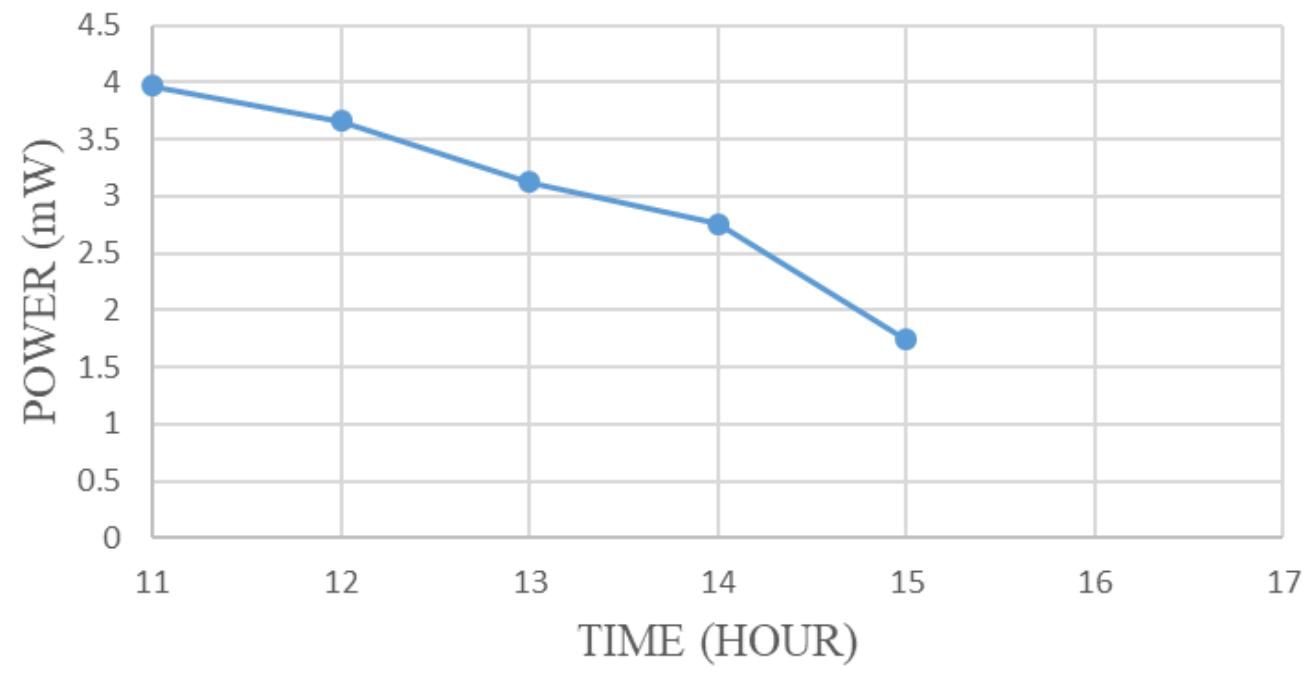

Figure 3.6: Effect of time on the maximum power

\subsection{Effect Of Time On The Power Conversion Efficiency}

There was a decrease in the power conversion efficiency from $4 \%$ at $11 \mathrm{am}$ to $3.67 \%$ at $12 \mathrm{pm}$ to $3.12 \%$ at $1 \mathrm{pm}$ to $2.76 \%$ at $2 \mathrm{pm}$ to $1.74 \%$ at $3 \mathrm{pm}$, this was due to the decrease in the maximum power generated from the Dye sensitized solar cell with respect to the power input from sunlight and its mainly as a result of the decrease in the short circuit current density as time goes on. It shows that power conversion efficiency is a function of power output with respect with the power input (Ru-YuanYang et al., 2012; Zhibin et al., 2012; Parth et al., 2016). 


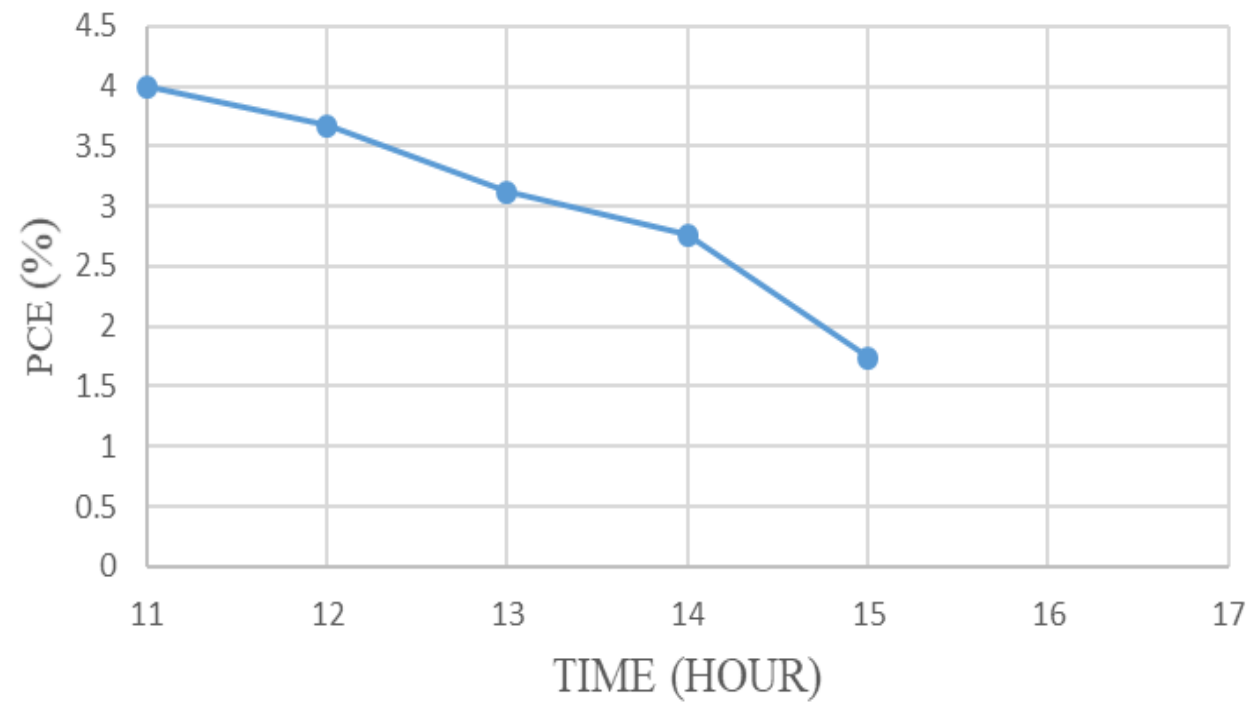

Figure 3.7: Effect of time on the power conversion efficiency

\subsection{Effect Of Time On The Fill Factor}

The increase in the fill factor as time goes on from 0.56 at $11 \mathrm{am}$ to 0.63 at $12 \mathrm{pm}$ to 0.65 at $1 \mathrm{pm}$ to 0.67 at $2 \mathrm{pm}$ to 0.68 at $3 \mathrm{pm}$ was as a result of better contact formation within the DSSC between the photo-anode, the electrolyte and carbon coated counter electrode when taking readings from the Dye-sensitized solar cell (Ru-YuanYang et al., 2012; Zhibin et al., 2012; Parth et al., 2016).

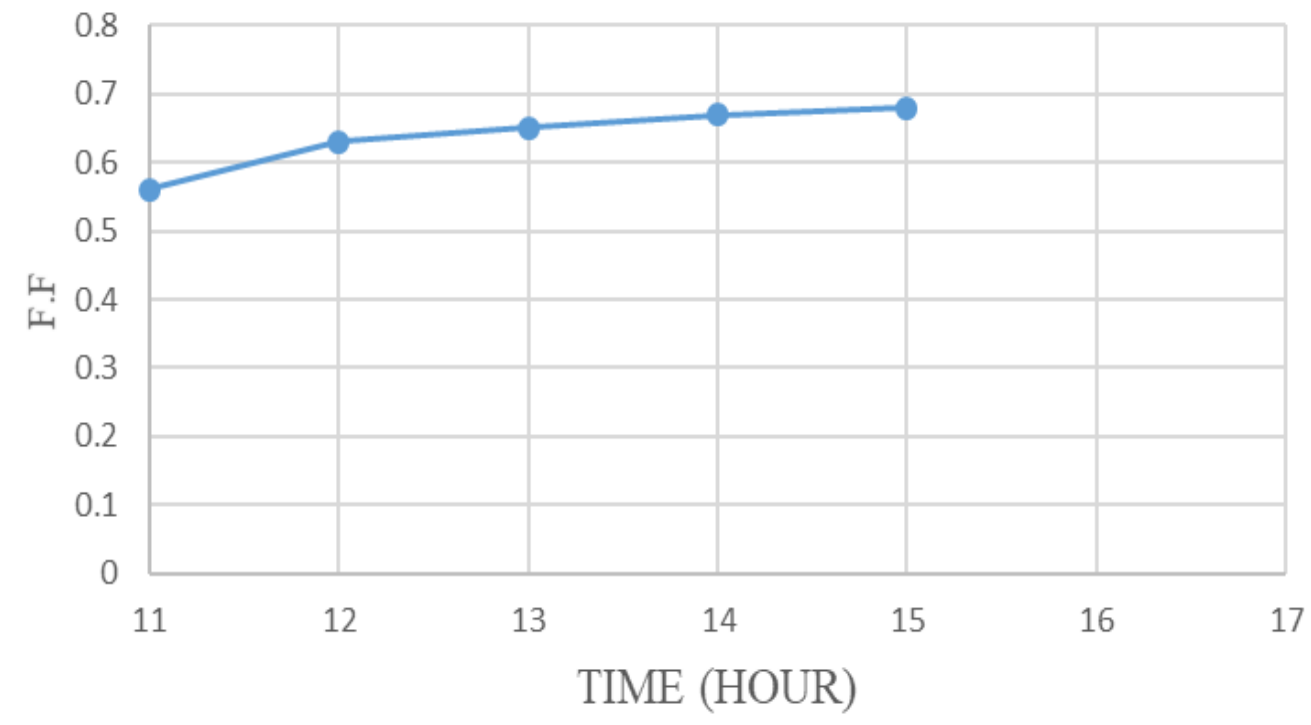

Figure 3.8: Effect of time on the Fill factor

\subsection{CONCLUSION}

This research was carried out with the aim of fabricating a dye sensitized solar cell, a low cost solar cell using spinach vegetable extract as sensitizing dye for Nano-crystalline $\mathrm{TiO}_{2}$ photo-electrodes. Soxhlet apparatus was used for the extraction of dye pigments from spinach vegetable. However, the existence of $\mathrm{C}-\mathrm{H}, \mathrm{N}-\mathrm{H}, \mathrm{O}-\mathrm{H}, \mathrm{C}=\mathrm{O}$ and $\mathrm{C}-\mathrm{O}$ stretches from the FTIR spectra indicated the presence of chlorophyll pigments in the spinach vegetable extract, absorption peaks from the UV-Visible absorption spectra for the spinach vegetable extract between $400(\mathrm{~nm})$ and $700(\mathrm{~nm})$ indicated a good sensitizing performance. In addition, titanium dioxide was deposited on the surface of the Fluorine-doped Tin Oxide coated glass using doctor blade method. The change in the current-voltage characteristics of the fabricated dye sensitized solar cell was observed under sunlight at 
$100\left(\mathrm{~mW} / \mathrm{cm}^{2}\right)$ as time goes on, at $11 \mathrm{am}$ (immediately after fabrication), 12pm, $1 \mathrm{pm} 2 \mathrm{pm}, 3 \mathrm{pm}$ and $4 \mathrm{pm}$. The power conversion efficiency of the DSSC was best at $11 \mathrm{am}$ with (4\%) immediately after it was fabricated and kept decreasing as time goes on to $1.74 \%$ at $3 \mathrm{pm}$. The open circuit voltage and Fill factor (F.F) got better but short circuit current density (Jsc) kept decreasing from $2.19(\mathrm{~mA})$ at $11 \mathrm{am}$ to $1.72(\mathrm{~mA})$ at $12 \mathrm{pm}$ to $1.39(\mathrm{~mA})$ at $1 \mathrm{pm}$ to $1.15(\mathrm{~mA})$ at $2 \mathrm{pm}$ to $0.68(\mathrm{~mA})$ at $3 \mathrm{pm}$ and then to $0(\mathrm{~mA})$ at $4 \mathrm{pm}$. Short circuit current density was $0(\mathrm{~mA})$ at $4 \mathrm{pm}$ as a result of electrolyte leakage due to the drying effect from sunlight.

However, the values of the power conversion efficiency of the Dye-sensitized solar cell shows that Dye sensitized solar cell fabricated using natural dyes could be a promising potential replacement for ruthenium dyes due to the simple and cost-effective preparation techniques involved in the extraction of the dye.

Hence, dye sensitized solar cells can act as an alternative source of renewable energy generation (electricity) in the future apart from the popularly used traditional silicon-based solar cells.

\section{ACKNOWLEDGMENT}

This study was supported financially by my sister, Awobokun Abimbola Balogun and my mother Mrs V.O Awobokun. Special thanks to Dr. M.U. Garba for his assistance, his time, energy, support and encouragement. My appreciation also goes to the Head of Chemical Engineering Department, Federal University of technology Minna, Dr. M. Abdulkadir and the entire staff of the department for their individual and collective contribution to the success of this study.

\section{REFERENCES}

1. Abubakar. S., Garba B., Zarma I. H. and Gaji M.M. (2010). Electricity Generation and the Present Challenges in the Nigerian Power Sector. International Journal of Scientific \& Engineering Research, https://www.researchgate.net/publication/228399732.

2. Ana Lúcia Moreira Pinto (2015). Light Harvesting in Solar Cells using Natural Pigments from Red Fruits Adsorbed to Mesoporous TiO2.

3. Askari M.B., Mirzaei M.A. and Mirhabibi M. (2015). Types of Solar Cells and Application. American Journal of Optics and Photonics, 3(5): 94-113.

4. Engr. Mansoor-ul-Hassan (2014). Power generation methods, techniques and economical strategy. International Technical Sciences Journal, Vol.1, No.1.

5. EPIA - Global market outlook for photovoltaics until 2016, p. 61, (2012).

6. Giuseppe C., Antonino B., Gaetano D.M., Aldo D.C. and Francesco B. (2014). Vegetable-based Dye-Sensitized Solar Cells. Chemical Society Reviews, 000309.R2.

7. Goetzberger A. and Hoffmann V.U. (2005). Photovoltaic Solar Energy Generation. Springer-Verlag Berlin Heidelberg, ISBN 3-540-23676-7.

8. Gratzel M. (2003). Dye-sensitized solar cells. Journal of Photochemistry and Photobiology, pp. 145-153.

9. Hassan K.T., Immaculata O.O., Simeon O.I., Pwafureino M., Chidinma I., Eugene U., Sylvester O., Michael K., Musa N., Victoria F.A., Bolade O.A., Linus N.O., Obioma U. and Wan J.J. (2017). Synthesis of Dye-Sensitized Solar Cells Using Chromophores from West African Plants. International Journal of Scientific \& Engineering Research, 10.14299/ijser.2017.06.005.

10. Hemmatzadeh and Mohammadi. (2013) Improving optical absorptivity of natural dyes for fabrication of efficient dyesensitized solar cells. Journal of Theoretical and Applied Physics, http://www.jtaphys.com/content/7/1/57

11. Katja Vozel. (2011). Seminar on Solar Cells $-1^{\text {st }}$ year, $2^{\text {nd }}$ cycle" Ljubljana.

12. Khalil E.J. (2011). Solar Cells - Dye-Sensitized Devices. InTech open Journals, ISBN 978-953-307-735-2.

13. Khan M.I. (2013). A Study on the Optimization of Dye-Sensitized Solar Cells. Graduate Theses and Dissertations, http://scholarcommons.usf.edu/etd/4519

14. Lawrence A., Shaichi S.J., Asif A., Nikia B., Sunil Y., Destiny B., William G., Alec G., Mintesinot J. and Jamal U. (2015). Creation of Natural Dye Sensitized Solar Cell by Using Nanostructured Titanium Oxide. Nanoscience and Nanoengineering, 3(3): 25-3.

15. Mary R.N.T., Joshua A.D., Vincent K., Suresh A., Anandan S., Saritha G. (2014). Natural Sensitizers for Dye Sensitized Solar Cell Applications. International Journal of Scientific and Engineering Research, Volume 5, Issue 3, ISSN 2229 5518.

16. Monzir S.A., Mahmoud B.A., Naji A.D., Amal M.A., Sofyan A.T., Taher M.E., Hatem S.G. (2015). Dye-Sensitized Solar Cells Using Fifteen Natural Dyes as Sensitizers of Nanocrystalline TiO2, Science, Technology and Development, 34 (3): 135-139.

17. Nelson J. (2003). The Physics of Solar Cells. Imperial College Press, London. ISBN 1-86094-340-3 
18. O’Regan B. and Gratzel, M. (1991). A low cost, high-efficiency solar cell based on dye sensitized colloidal TiO2 films. Journal of Photochemistry and Photobiology, Vol. 353, pp. 737-739.

19. Parth B., Kavita P., Pankaj Y., Brijesh T. and Manoj K. (2016). Impedance Spectroscopic Investigation of the Degraded Dye-Sensitized Solar Cell due to Ageing. International Journal of Photoenergy, http://dx.doi.org/10.1155/2016/8523150.

20. Pratiwi D. D., Nurosyid F., Supriyanto A., and Suryana R. (2016). Optical properties of natural dyes on the dyesensitized solar cells (DSSC) performance. International Conference on Physics and its Applications, 10.1088/17426596/776/1/012007.

21. Ridwan M.A., Noor E., Rusli M.S., Akhiruddin. (2018). Fabrication of dye-sensitized solar cell using chlorophylls pigment from sargassum. International Conference on Tropical Studies and Its Application, 144012039.

22. Ru-YuanYang, Huang-YuChen, and Fu-DerLai (2012). Performance Degradation of Dye-Sensitized Solar Cells Induced by Electrolytes. Advances in Materials Science and Engineering, 10.1155/2012/902146.

23. Smestad G.P. and Gratzel M. (1998). Demonstrating Electron Transfer and Nanotechnology: A Natural Dye-Sensitized Nanocrystalline Energy Converter. Journal of Chemical Education, Vol. 75 No. 6, pp. 752-756.

24. Sofyan A. T., Taher M.E., Hatem S.E., Monzir S.A. (2013). Dye-sensitized solar cells using fresh and dried natural dyes. International Journal of Scientific \& Engineering Research, https://www.researchgate.net/publication/275567845.

25. Suryawanshi A.D. Bhise R.B and Suryawanshi D.D. (2015). Study of nutrient stresses in plants by FTIR spectroscopy. International journal of chemical and physical sciences, ISSN:23196602.

26. Syafinar R., Gomesh N., Irwanto M., Fareq M. and Irwan Y.M. (2015). Optical characterization using nature based dye extracted from hibiscus's flower. ARPN Journal of Engineering and Applied Sciences, VOL. 10, NO. 15.

27. Temitope A., Chidi U. and Joseph O. (2015). Phytochemical Analysis of Leaf-Extracts from Eight Tropical Trees: Prospects for Environmentally-Friendly Dye Compounds for Smart Windows. International Journal of Scientific \& Engineering Research, Volume 6, 2229-5518. http://www.ijser.org.

28. Umer M., Saleem-ur R., Khalil H., Hussein I., and Reddy B.V.S. (2014). Recent Advances in Dye Sensitized Solar Cells. Hindawi Publishing Corporation, 974782.

29. Zhibin L., Hongwei W., Xin C., Yongping F., Dan W., Zengze C. and Dechun Z. (2012). Influence of Electrolyte Refreshing on the photo-electrochemical performance of fiber-shaped dye sensitized solar cells. International journal of photo-energy, http://dx.doi.org/10.1155/2012/104597. 